\title{
Persepsi Masyarakat Terhadap Hutan Kota Di Kawasan Bandara Deo Kota Sorong (Studi Kasus di Kelurahan Malaingkedi dan Kelurahan Remu Selatan)
}

\author{
Muzna A.A. Gafur ${ }^{1),}$ Lona Helti Nanlohy ${ }^{2)}$ Flora Veronika Naa ${ }^{3)}$ \\ 1) Dosen Fakultas Pertanian UMS \\ 2) Dosen Fakultas Pertanian UMS \\ 3) Mahasiswa Sarjana Fakultas Pertanian UMS
}

\begin{abstract}
Abstrak
Persepsi sangat mempengaruhi perilaku seseorang terhadap lingkungannya. Seseorang yang mempunyai persepsi yang benar mengenai konservasi kemungkinan besar orang tersebut berperilaku positif terhadap upaya-upaya pelestarian lingkungan. Dengan demikian persepsi dapat mempengaruhi orang dalam menentukan sikap dan tindakannya sehingga orang akan ikut berperan aktif dan berpartisipasi di dalam proses pembangunan. Metode yang digunakan dalam penelitian adalah metode survei melalui wawancara secara langsung dan pengisian kuisioner. Metode survei merupakan tipe pendekatan dalam penelitian, yang ditujukan pada sejumlah individu atau kelompok. Persepsi masyarakat Kelurahan Malaingkedi dan Kelurahan Remu Selatan terhadap aspek hutan kota menunjukan bahwa masyarakat sudah sangat memahami keberadaan dan manfaat hutan kota bagi kehidupan masyarakat sekitar hutan kota.
\end{abstract}

Kata kunci: Persepsi, Masyarakat, Hutan Kota

\section{PENDAHULUAN}

Perkembangan kota akibat peningkatan jumlah penduduk kota yang semakin tinggi menuntut adanya pembangunan kota untuk terus berkembang berupa pembangunan sarana dan prasarana untuk melayani warga masyarakat. Dengan banyaknya jumlah sarana dan prasarana sebagai kebutuhan bagi masyarakat kota mengakibatkan berkurangnya lahanlahan bervegetasi yang dikonversi menjadi tempat perkantoran, pertokoan, tempat rekreasi, industri dan lain sebagainya, sehingga kestabilan ekosistem lingkungan perkotaan menjadi menurun (Dahlan 2004). Pembangunan fisik untuk memenuhi kebutuhan warganya dilakukan dengan merubah lanskep alam dan tata ruang wilayah dan berakibat pada penurunan daya dukung lingkungan dan jasa lingkungan.

Ketidakharmonisan hubungan manusia dengan lingkungan mengakibatkan keadaan lingkungan manusia di perkotaan hanya maju secara ekonomi namun mundur dari segi ekologi. Nilai kestabilan kota secara ekologi sangat penting sama pentingnya dengan nilai kestabilan secara ekonomi. Oleh karena itu terganggunya kestabilan ekosistem perkotaan maka alam akan menunjukan reaksinya berupa meningkatnya suhu udara diperkotaan, menurunnya air tanah, banjir, penurunan permukaan tanah, instrusi air laut, abrasi pantai, 
pencemaran air, pencemaran logam berat, pencemaran udara seperti meningkatnya kadar karbondioksida, oksida nitrogen, belerang, dan debu.

Menurunnya kualitas lingkungan perkotaan akibat pencemaran debu dan kebisingan menyebabkan kota menjadi sakit, sehingga dapat mempengaruhi kinerja dan produktifitas dari masyarakat menjadi buruk. Oleh karena itu, perlu dilakukan upaya-upaya pengelolaan lingkungan. Salah satu upaya pengelolaan di perkotaan adalah dengan membangun hutan kota dalam bentuk taman kota. Konsep dasarnya adalah memaksimal keberadaan dan fungsi hutan dan taman serta berbagai bentuk penghijauan kota lainnya untuk mengatasi masalah lingkungan yang ada. Keuntungan dalam membangun hutan kota adalah tidak membutuhkan perawatan yang intensif, sehingga dana yang diperlukan untuk perawatan dan pemeliharaannya relatif murah. Manfaat yang dapat dihasilkan oleh hutan kota berupa taman kota untuk menjadikan kota lebih bersih dari pencemaran udara serta untuk menjadikan kota yang sejuk, sehat dan nyaman (Dahlan 2004).

$$
\text { Untuk mengimbangi }
$$

pembangunan yang tidak seimbang antara keperluan ekonomi, ekologi, dan sosial membuat kualitas lingkungan kota menjadi rusak dan tidak terkendali maka dibutuhkan peningkatan fasilitas, sarana, dan prasarana baik dari segi kualitas dan kuantitas. Hutan Kota secara fungsional dan estetika merupakan sarana kota yang dapat memperbaiki kualitas kota baik secara fisik maupun psikis. Keberadaan hutan kota bagi masyarakat kota sangat penting, karena dapat dijadikan sebagai area terbuka yang mampu mengakomodasi kebutuhan rekreasi disela kesibukan lingkungan perkotaan. Pada umumnya, hutan kota yang ada hanya berfungsi sebagai penghias kota disamping fungsi sosial bagi warga kota. Padahal hutan kota dapat dimanfaatkan untuk fungsi yang lebih luas, yaitu dengan memberdayakannya sebagai ruang terapi. Pengembangan fungsi terapi di ruang luar telah dikenal di pusat-pusat pelayanan kesehatan. Kehadiran taman terapeutik di pusat pelayanan kesehatan ini berimplikasi tidak saja meningkatkan kualitas lingkungan yang lebih estetis, tetapi juga untuk meningkatkan fungsi pelayanan kesehatan.

Menurut Surata (1993) persepsi sangat mempengaruhi perilaku seseorang terhadap lingkungannya. Seseorang yang mempunyai persepsi yang benar mengenai konservasi kemungkinan besar orang tersebut berperilaku positif terhadap upayaupaya pelestarian lingkungan. Dengan demikian persepsi dapat mempengaruhi orang dalam menentukan sikap dan tindakannya sehingga orang akan ikut berperan aktif dan berpartisipasi di dalam proses pembangunan. Surata (1993) menyatakan tidak ada yang lebih mendasar dalam menangani masalah lingkungan selain membangun persepsi lingkungan di kalangan masyarakat. Selain itu, persepsi juga dapat dijadikan sebagai bahan masukan kepada Pemerintah Kota dalam pengelolaan dan pengembangan hutan kota yang ada agar menjadi lebih baik.

Berdasarkan Peraturan Daerah Kota Sorong Nomor 22 Tahun 2014 tentangPenataan Ruang Terbuka Hijau dan Peraturan Daerah Kota Sorong Nomor 27 tahun 2014 tentang Pengelolaan Pertamanan dan Dekorasi Kota Pasal 1 ayat 17 mengatakan bahwa Hutan Kota adalah suatu hamparan lahan yang bertumbuhan pada pohonpohon yang kompak dan rapat di dalam 


\section{Median Volume IX Nomor 1 Bulan Februari 2017}

wilayah perkotaan baik pada tanah negara maupun tanah hak, yang ditetapkan sebagai hutan kota oleh pejabat yang berwenang.Pasal 1 Ayat 9 yang mengatakan bahwa Taman Kota adalah sebidang tanah yang merupakan bagian dari ruang terbuka hijau kota yang mempunyai batas tertentu, ditata dengan serasi, lestari dan indah dengan menggunakan material taman, material buatan dan unsure-unsur alam untuk menjadi fasilitas sosial kota, pengaman sarana kota dan mampu menjadi areal penyerapan air. Oleh karena itu, perlu diketahui sampai sejauh manakah persepsi masyarakat terhadap Hutan Kota berupa Taman Kota di Kota Sorong terutama di kawasan Bandara Deo Sorong.

Tujuan dari penelitian ini adalah : mengetahui persepsi masyarakat terhadap hutan kota berupa taman kota di depan kawasan Bandara Deo Kota Sorong.

\section{METODE PENELITIAN}

Penelitian ini dilaksanakan
diKelurahan Malaingkedi dan Kelurahan Remu SelatanKota Sorong. Penelitian dilaksanakan selama 1 bulan yaitu bulan Juli 2015.

Bahan dan alat yang digunakan pada penelitian ini yaitu Lembaran Kuisioner, Alat tulis menulis dan Kamera.

Metode yang digunakan dalam penelitian adalah metode survei melalui wawancara secara langsung dan pengisian kuisioner.Metode survei merupakan tipe pendekatan dalam penelitian, yang ditujukan pada sejumlah individu atau kelompok.

Variabel penelitian meliputi : Persepsi masyarakat (responden) berupa a. Aspek Pengenalan Hutan Kota b. Aspek manfaat Hutan Kota

c. Aspek Pengelolaan Hutan Kota

Pemilihan responden dilakukan dengan cara Purpossive Random Sampling yaitu pengambilan contoh secara acak dengan keadaan yang kita kehendaki. Pengambilan responden dilakukan pada kawasan Kelurahan Malaingkedi RW.01/RT.02 dan Kelurahan Kelurahan Remu Selatan RW.04/RT.04Pemilihan daerah contoh tersebut dimaksudkan dapat mewakili permukiman berdasarkan lokasi penelitian.

Data yang dikumpulkan adalah data primer dan sekunder. Data primer dalam penelitian ini diperoleh dari hasil wawancara. Responden yang dipilih adalah masyarakat umum yang berdomisili di Kelurahan Malaingkedi RW.01/RT.02 dan Kelurahan Kelurahan Remu Selatan RW.04/RT.04.Pemilihan Kedua Kelurahan (RW dan RT) tersebut disebabkan karena kedua kelurahan tersebut merupakan kelurahan yang bersinggungan langsung dengan hutan kota berupa taman kota yang berada di depan Bandara Deo Kota Sorong.Jumlah responden di Kelurahan Malaingkedi RW.01/RT.02 adalah 12 responden yaitu $15 \%$ dari $80 \mathrm{KK}$ dan di Kelurahan Remu Selatan RW.04/RT.04 adalah 22 responden yaitu $15 \%$ dari $150 \mathrm{KK}$ yang berada di kelurahan tersebut. Responden yang diwawancarai tersebut merupakan kepala keluarga (KK) yang dipilih secara acak dan dimaksudkan dapat mewakili. Selain itu,data diperoleh juga dari pihak pengelola dinas Lingkungan Hidup.

Pengolahan data dilakukan dengan cara menterjemahkan data ke dalam bentuk tabel agar lebih mudah dimengerti. Data yang ada di dalam tabel kemudian dilakukan pengolahan sesuai dengan aspek yang dikaji. Hasil 
dari pengolahan data berupa persentase atas jawaban yang telah diberikan oleh setiap responden.

\section{HASIL DAN PEMBAHASAN}

\section{A. Karakteristik Responden}

Persepsi masyarakat terhadap hutan kota tidak terlepas dari karakteristik masyarakat tersebut. Oleh karena itu, perlu diketahui karakteristik responden agar dapat mewakili keseluruhan populasi. Karakteristik responden pada penelitian ini dilihat berdasarkan tingkat pendidikan, umur dan jenis pekerjaan. Selain itu, karakteristik responden tersebut juga digunakan sebagai parameter persepsi, sehingga dapat diketahui faktor yang mempengaruhi tingkat persepsi responden terhadap hutan kota. Hal ini sesuai dengan pernyataan Surata (1993) yang menyatakan persepsi ditentukan oleh faktor internal seperti kecerdasan, minat, emosi, pendidikan, pendapatan, kapasitas alat indera dan jenis kelamin.

Responden yang dipilih adalah masyarakat umum yang berdomisili di Kelurahan Malaingkedi RW.01/RT.02 dan Kelurahan Remu Selatan RW.04/RT.04. Pemilihan Kedua Kelurahan (RW dan RT) tersebut disebabkan karena kedua kelurahan tersebut merupakan kelurahan yang bersinggungan langsung dengan hutan kota berupa taman kota yang berada di depan Bandara Deo Kota Sorong. Jumlah responden di Kelurahan Malaingkedi RW.01/RT.02 adalah 12 responden yaitu $15 \%$ dari $80 \mathrm{KK}$ dan di Kelurahan Remu Selatan RW.04/RT.04 adalah 22responden yaitu $15 \%$ dari $150 \mathrm{KK}$ yang berada di kelurahan tersebut

\section{Tingkat Pendidikan Responden}

Pendidikan merupakan salah satu faktor pembentuk pola pikir seseorang dalam menyingkapi perubahan yang terjadi. Semakin tinggi tingkat pendidikan seseorang akan memiliki daya adaptasi yang cepat terhadap perubahan yang ada..

Menurut Mauludin (1994) faktor pendidikan dapat dijadikan faktor penduga persepsi paling baik dibandingkan faktor-faktor lainnya seperti faktor umur, jenis kelamin dan pekerjaan. Hal ini dikarenakan terdapat hubungan antara informasi dengan tingkat persepsi bahwa semakin banyak informasi yang diterima oleh masyarakat tingkat persepsi juga semakin tinggi

Karakteristik responden untuk tingkat pendidikan dapat dilihat pada tabel 1 di bawah ini.

Tabel 1. Tingkat pendidikan responden Pada Kelurahan Malaingkedi dan Kelurahan Remu selatan Kota Sorong

\begin{tabular}{|c|c|c|c|c|c|}
\hline \multirow[b]{2}{*}{ No } & \multirow[b]{2}{*}{$\begin{array}{c}\text { Tingkat } \\
\text { Pendidikan }\end{array}$} & \multicolumn{2}{|c|}{ Kelurahan Malaingkedi } & \multicolumn{2}{|c|}{ Kelurahan Remu Selatan } \\
\hline & & $\begin{array}{c}\text { Jumlah } \\
\text { Responden }\end{array}$ & $\begin{array}{l}\text { Persentasi } \\
(\%)\end{array}$ & $\begin{array}{c}\text { Jumlah } \\
\text { Responden }\end{array}$ & $\begin{array}{c}\text { Persentasi } \\
(\%)\end{array}$ \\
\hline 1. & Tidak Sekolah & 0 & 0 & 0 & 0 \\
\hline 2. & SD & 0 & 0 & 1 & 4,55 \\
\hline 3. & SMP & 3 & 25 & 2 & 9,09 \\
\hline 4. & SMA & 8 & 66,67 & 18 & 81,81 \\
\hline 5. & Perguruan Tinggi & 1 & 8,33 & 1 & 4,55 \\
\hline & Jumlah & 12 & 100 & 22 & 100 \\
\hline
\end{tabular}

Sumber : Data Olahan Penelitian 2015 


\section{Median Volume IX Nomor 1 Bulan Februari 2017}

Berdasarkan tabel 1 tersebut pada umumnya tingkat pendidikan pada kedua Kelurahan tersebut yaitu SMA Kelurahan Malaingkedi sebesar $66,67 \%$, dan keluarahan Remu Selatan sebesar $81,81 \%$. Hal ini menggambarkan bahwa tingkat pendidikan responden tergolong tinggi. Tingkat pendidikan yang tergolong tinggi tersebut akan dihubungkan dengan tingkat persepsi masyarakat terhadap aspek hutan kota yang dikaji. Faktor pendidikan dalam pengaruhnya terhadap persepsi juga telah dibuktikan melalui penelitian yang dilakukan oleh Purwanto (1998) menyatakan bahwa tingkat pendidikan menunjukkan hubungan yang cukup erat terhadap persepsi masyarakat. Hubungan tersebut menunjukkan semakin tinggi tingkat pendidikan maka persentase nilai persepsi semakin besar, sedangkan
Zakih (1997) yang membandingkan persepsi masyarakat kota modern dengan masyarakat kampung kota terhadap hutan kota menyatakan media massa merupakan sumber yang efektif dalam menyebarkan informasi. Hal ini dikarenakan terdapat hubungan antara informasi dengan tingkat persepsi bahwa semakin banyak informasi yang diterima oleh masyarakat tingkat persepsi juga semakin tinggi.

\section{Umur Responden}

Umur merupakan salah satu faktor yang mempengaruhi kemampuan seseorang dalam mengemukakan suatu pandangan atau ide dalam hal ini bagaimana persepsinya tentang suatu masalah.Tingkat umur responden secara rinci dapat dilihat pada tabel 2 dibawah ini.

Tabel 2. Tingkat Umur Responden Pada Kelurahan Malaingkedi dan Kelurahan Remu selatan Kota Sorong

\begin{tabular}{cccccc}
\hline \multirow{2}{*}{ No } & \multirow{2}{*}{$\begin{array}{c}\text { Kelas Umur } \\
(\text { Thn })\end{array}$} & $\begin{array}{c}\text { Kelurahan Malaingkedi } \\
\text { Responden }\end{array}$ & $\begin{array}{c}\text { Persentasi } \\
(\%)\end{array}$ & $\begin{array}{c}\text { KelurahanRemu Selatan } \\
\text { Responden }\end{array}$ & $\begin{array}{c}\text { Persentasi } \\
(\%)\end{array}$ \\
\hline 1 & $25-29$ & 1 & 8,33 & 2 & 9,09 \\
2 & $30-34$ & 2 & 16,67 & 5 & 22,73 \\
3 & $35-39$ & 1 & 8,33 & 4 & 18,18 \\
4 & $40-44$ & 3 & 25,00 & 8 & 36,36 \\
5 & $45-49$ & 5 & 41,67 & 3 & 13,64 \\
6 & $50-54$ & 0 & 0 & 0 & 0 \\
\hline & Jumlah & 12 & 100 & 22 & 100 \\
\hline
\end{tabular}

Sumber : Data Olahan Penelitian 2015

Pada Tabel 2 pada Kelurahan Malaingkedi tingkat umur responden bervariasi tingkat umur tertinggi berada pada kelas umur 45 - 49 tahun yang besarnya $41,67 \%$ dan sedangkan di Kelurahan Remu Selatan tingkat umur yang mendominasi berada pada kelas umur 40 - 44 tahun yaitu sebesar $36,36 \%$. Tingkatan umur responden tersebut dapat dikatakan bahwa responden secara umum tergolong sudah berpengalaman. Hal ini sesuai dengan pernyataan Vandemark dan Leth (1971) dalam Surata (1993) yang menyebutkan bahwa persepsi individu salah satunya dibatasi oleh perbedaan pengalaman. Selain dari tingkat pendidikan dan umur, dilihat juga karakteristik pada jenis pekerjaan. 


\section{Median Volume IX Nomor 1 Bulan Februari 2017}

Lebih lengkap jenis pekerjaan yang ada dapat dilihat pada Tabel 2 di bawah ini.

\section{Pekerjaan Responden}

Pekerjaan merupakan salah satu faktor yang juga berpengaruh terhadap kemampuan seseorang dalam mengemukakan suatu pandangan atau ide dalam hal ini bagaimana persepsinya tentang suatu masalah terutama persepsinya tentang hutan kota.Karakteristik pekerjaan responden secara rinci dapat dilihat pada tabel 3dibawah

ini.

Tabel 3. Pekerjaan Responden Pada Kelurahan Malaingkedi dan Kelurahan Remu selatan Kota Sorong

\begin{tabular}{llcccc}
\hline \multirow{2}{*}{ No } & \multirow{2}{*}{ Pekerjaan } & \multicolumn{2}{c}{ Kelurahan Malaingkedi } & \multicolumn{2}{c}{ Kelurahan Remu Selatan } \\
\cline { 3 - 6 } & & $\begin{array}{c}\text { Jumlah } \\
\text { Responden }\end{array}$ & $\begin{array}{c}\text { Persentasi } \\
(\%)\end{array}$ & $\begin{array}{c}\text { Jumlah } \\
\text { Responden }\end{array}$ & $\begin{array}{c}\text { Persentasi } \\
(\%)\end{array}$ \\
\hline 1 & Petani & 2 & 16,67 & 1 & 4,55 \\
2 & Nelayan & 0 & 0 & 1 & 4,55 \\
3 & Buruh & 1 & 8,33 & 2 & 9,09 \\
4 & Swasta & 8 & 66,67 & 17 & 77,3 \\
5 & PNS & 1 & 8,33 & 1 & 4,55 \\
\hline & Jumlah & 12 & 100 & 22 & 100 \\
\hline
\end{tabular}

Sumber : Data Olahan Penelitian 2015

Berdasarkan Tabel 3 terdapat perbedaan jenis pekerjaan pada setiap Kelurahan jenis pekerjaan yang ada sebagian besar adalah swasta yaitu masing-masing sebesar 66,67 untuk kelurahan Malaingkedi dan 77,27\% untuk kelurahan Remu selatan.

\section{A. Persepsi Masyarakat Terhadap Hutan Kota}

Persepsi adalah suatu proses untuk membuat penilaian (judgment) mengenai berbagai macam hal yang terdapat di lapangan penginderaan seseorang

Tabel 4. Persepsi Masyarakat Kelurahan Malaingkedi Terhadap Aspek Pengenalan Hutan Kota

\begin{tabular}{lllcc}
\hline No & \multicolumn{1}{c}{ Uraian } & & Responden & Persentasi $(\%)$ \\
\hline 1. & Pengetahuan Masyarakat Tentang Hutan & Ya & 10 & 83,33 \\
& Kota & Tidak & 2 & 16,67 \\
\hline 2 & Masyarakat setuju dengan adanya hutan & Ya & 12 & 100 \\
& kota & Tidak & 0 & 0 \\
\hline \multirow{2}{*}{ Keberadaan Hutan kota di Kota Sorong } & Ada & 10 & 83,33 \\
& & Tidak & 2 & 16,67 \\
\hline \multirow{2}{*}{ Kondisi hutan kota di Kota Sorong } & Baik & 2 & 16,67 \\
& & Rusak & 8 & 66,67 \\
& & Tidak Tahu & 2 & 16,67 \\
\hline
\end{tabular}

Sumber : Data Olahan Penelitian 2015
1. Persepsi Masyarakat Terhadap Aspek Pengenalan Hutan Kota

a. Persepsi Masyarakat Kelurahan Malaingkedi Terhadap Aspek Pengenalan Hutan Kota

Persepsi masyarakat pada aspek pengenalan hutan kota dimaksudkan untuk mengetahui tingkat pengenalan dan pengetahuan masyarakat tentang aspek pengenalan hutan kota. Lebih jelasnya penilaian persepsi masyarakat secara umum terhadap aspek pengenalan hutan kota dapat dilihat pada tabel 4 . 
Tabel 4 menunjukan bahwa masyarakat Kelurahan Malaingkedi pada umumnya mengetahui yang dimaksud dengan hutan kota, hal ini tergambar sebanyak 83,33\% menyatakan bahwa mereka mengetahui apa yang dimaksudkan dengan hutan kota, hal ini membuktikan bahwa sebagain besar masyarakat/ responden sudah mengerti dan memahami apa yang dimaksudkan dengan hutan kota dimana informasi yang mereka dapatkan berasal dari berbagai sumber, ada yang mendapatkan informasi dari majalah, media elektronik maupun dari teman atau saudara. Masyarakat/Responden juga setuju dengan adanya hutan kota, $100 \%$, karena masyarakat/responden berpendapat bahwa dengan adanya hutan kota akan memberikan kesejukan, keindahan dan kenyamanan serta akan mengurangi polusi udara. Masyarakat/responden $\quad(66,67 \%)$ mengatakan bahwa kondisi hutan kota didepan Bandara Deo dalam kondisi rusak dan tidak terawat dengan baik, masyarakat mengharapkan adanya peran aktif dari pemerintah Kota Sorong untuk memperhatikan keberadaan hutan kota yang ada di kota Sorong sehingga kondisi hutan kota yang rusak akan terawat dengan baik. Masyarakat/responden berpendapat bahwa hutan kota yang di butuhkan di kota Sorong adalah Taman kota berupa pohon-pohon yang rindang dan hijau sehingga dapat memberikan kesejukan dan kenyamanan bagi masyarakat kota. Hal ini terkait dengan keindahan Kota Sorong yang kurang baik akibat banyaknya pencemaran yang terjadi seperti pencemaran debu dan tingkat kebisingan yang tinggi. Tingkat pemahaman masyarakat Kelurahan Malaingkedi dapat dipengaruhi oleh pengetahuan yang didapatkan dari berita dan informasi yang berhubungan dengan hal-hal mengenai hutan kota. Selain itu, faktor pendidikan juga dapat mempengaruhi tingkat persepsi seseorang. Tingkat persepsi yang tinggi tersebut menggambarkan bahwa masyarakat sudah memahami tentang aspek pengenalan hutan kota yang dipengaruhi oleh banyaknya informasi mengenai hal-hal terkait dengan hutan kota. Hal ini sesuai dengan pernyataan Wibowo (1987) dalam Pamungkas (2006). yang menyatakan bahwa persepsi adalah suatu gambaran pengertian serta interpretasi seseorang mengenai suatu obyek, terutama bagaimana orang tersebut menghubungkan informasi itu dengan dirinya dan lingkungan ia berada.

\section{b. Persepsi Masyarakat Kelurahan Remu Selatan Terhadap Aspek Pengenalan Hutan Kota}

Persepsi masyarakat Kelurahan Remu Selatan pada aspek pengenalan hutan kota dapat dilihat pada tabel 5 . 


\section{Median Volume IX Nomor 1 Bulan Februari 2017}

Tabel 5. Persepsi Masyarakat Kelurahan Remu Selatan Terhadap Aspek Pengenalan Hutan Kota

\begin{tabular}{cllcc}
\hline No. & \multicolumn{1}{c}{ Uraian } & & Responden & Persentasi (\%) \\
\hline 1. & Pengetahuan Masyarakat & Ya & 19 & 86,36 \\
& Tentang Hutan Kota & Tidak & 3 & 13,64 \\
\hline 2 & Masyarakat setuju dengan & Ya & 22 & 100 \\
& adanya hutan kota & Tidak & 0 & 0 \\
\hline \multirow{2}{*}{3} & Keberadaan Hutan kota di & Ada & 19 & 86,36 \\
& Kota Sorong & Tidak & 3 & 13,64 \\
\hline \multirow{2}{*}{4} & Kondisi hutan kota di Kota & Baik & 0 & 0 \\
& Sorong & Rusak & 19 & 95,45 \\
& & Tidak Tahu & 3 & 4,55 \\
\hline
\end{tabular}

Sumber : Data Olahan Penelitian 2015

Tabel 5 menunjukan bahwa masyarakat/responden Kelurahan Remu Selatan pada umumnya mengetahui yang apa yang dimaksud dengan hutan kota, 86,36\% menyatakan bahwa mereka mengetahui apa yang dimaksuskan dengan hutan kota, hal ini membuktikan bahwa sebagain besar masyarakat/ responden sudah mengerti dan memahami apa yang dimaksudkan dengan hutan kota dimana informasi yang mereka dapatkan berasal dari berbagai sumber, ada yang mendapatkan informasi dari majalah, media elektronik maupun dari teman atau saudara. Masyarkat/responden setuju dengan adanya hutan kota (100\%.) karena masyarakat/responden berpendapat bahwa dengan adanya hutan kota akan memberikan kesejukan, keindahan dan kenyamanan serta akan mengurangi polusi udara. Sebagian besar responden 95,45\% mengatakan bahwa kondisi hutan kota didepan Bandara Deo dalam kondisi rusak dan tidak terawat dengan baik, masyarakat mengharapkan adanya peran aktif dari pemerintah Kota Sorong untuk memperhatikan keberadaan hutan kota yang ada di kota Sorong. Masyarakat/responden Kelurahan Remu Selatan $(100 \%)$ berpendapat bahwa hutan kota sangat butuhkan di kota Sorong. Hal ini terkait dengan keindahan Kota Sorong yang kurang baik akibat banyaknya pencemaran yang terjadi seperti pencemaran debu dan tingkat kebisingan yang tinggi. Tingkat pemahaman masyarakat Kelurahan Remu Selatan dapat dipengaruhi oleh pengetahuan yang didapatkan dari berita dan informasi yang berhubungan dengan hal-hal mengenai hutan kota. Selain itu, faktor pendidikan juga dapat mempengaruhi tingkat persepsi seseorang.

\section{Persepsi Masyarakat Terhadap}

Aspek Pemanfaatan Hutan Kota

a. Persepsi Masyarakat Kelurahan Malaingkedi Terhadap Aspek Pemanfaatan Hutan Kota

Masyarakat Kelurahan

Malaingkedi menyatakan manfaat dari hutan kota yang dapat dimanfaatkan terhadap kenyamanan, keindahan dan kesejukan. Hal ini dikarenakan sudah banyak terjadi pencemaran di kota Sorong terutama pencemaran udara akibat polusi udara dan asap kendaraan bermotor. Tingkat persepsi masyarakat Kelurahan Malaingkedi terhadap aspek pemanfaatan hutan kota secara rinci dapat dilihat pada Tabel 6 di bawah ini, 
Tabel 6. Tingkat Persepsi Masyarakat Kelurahan Malaingkedi Terhadap Aspek Pemanfaatan Hutan Kota.

\begin{tabular}{lllcc}
\hline No. & \multicolumn{1}{c}{ Uraian } & & Responden & $\begin{array}{c}\text { Persentasi } \\
(\%)\end{array}$ \\
\hline 1. & $\begin{array}{l}\text { Hutan kota bermanfaat bagi } \\
\text { Masyarakat }\end{array}$ & Ya & 12 & 100 \\
\hline tidak & $\begin{array}{l}\text { Mengurangi } \\
\text { polusi udara } \\
\text { Keindahan }\end{array}$ & 12 & 0 \\
\hline $\begin{array}{l}\text { Bentuk manfaat yang dapat } \\
\text { dirasakan }\end{array}$ & $\begin{array}{l}\text { Rekreasi } \\
\text { setuju }\end{array}$ & 5 & 100 \\
\hline $\begin{array}{l}\text { Setujukah anda apabila dengan } \\
\text { adanya hutan kota, anda } \\
\text { mendapatkan kesegaran }, \\
\text { kesejukan dan lingkungan yang } \\
\text { bersih }\end{array}$ & tidak & 12 & 75 \\
\hline $\begin{array}{l}\text { Setujukah anda bahwa masalah } \\
\text { pencemaran lingkungan dikota } \\
\text { Sorong, salah satu alternative } \\
\text { pemecahannya adalah dengan } \\
\text { mengembangkan program hutan } \\
\text { kota. }\end{array}$ & setuju & 0 & 100 \\
\hline tidak & 0 & 0 \\
\hline
\end{tabular}

Sumber : Data Olahan Penelitian 2015

Tabel 6 menunjukan bahwa masyarakat/responden Kelurahan Malaingkedi (100\%) menyatakan bahwa bentuk pemanfaatan hutan kota Masyarakat Kelurahan Malaingkedi sebanyak $100 \%$ menyatakan bahwa manfaat hutan kota adalah untuk mencegah polusi udara. Polusi udara dapat dicegah dengan menanam pohon karena pohon bermanfaat memberikan udara lebih segar dan bersih. Masyarakat Kelurahan Malaingkedi $100 \%$ setuju dengan adanya hutan kota akan memberikan kesegaran, kesejukan dan keindahan kota dan masalah pencemaran dapat teratasi dengan adanya pengembangan program hutan kota. Dengan demikian tingkat persepsi masyarakat Kelurahan Malaingkedi terhadap aspek pemanfaatan hutan kota tergolong tinggi. Bentuk dukungan dari dapat dirasakan manfaatnya sebagai hutan kota bagi masyarakat, walaupun luasan yang ada tergolong kecil untuk dikatakan sebagai hutan kota.

masyarakat tersebut dapat dijadikan sebagai bahan masukan dalam program pengembangan dan pembangunan hutan kota di Kota Sorong. Pemerintah dapat mempertimbangkan aspirasi dari masyarakat tersebut sebagai pengambilan kebijakan dan keputusan dalam program pengembangan hutan kota.

\section{b. Persepsi Masyarakat Kelurahan Remu Selatan Terhadap Aspek Pemanfaatan Hutan Kota}

Tingkat persepsi masyarakat Kelurahan Remu Selatan terhadap aspek pemanfaatan hutan kota secara rinci dapat dilihat pada Tabel $7 \mathrm{di}$ bawah ini. 
Tabel 7. Tingkat Persepsi Masyarakat Kelurahan Remu Selatan Terhadap Aspek Pemanfaatan Hutan Kota.

\begin{tabular}{lllcc}
\hline No. & \multicolumn{1}{c}{ Uraian } & Responden & Persentasi (\%) \\
\hline 1. $\begin{array}{l}\text { Hutan kota bermanfaat bagi } \\
\text { Masyarakat }\end{array}$ & Ya & 22 & 100 \\
& tidak & 0 & 0 \\
\hline 2. $\begin{array}{l}\text { Mengurangi } \\
\text { dirasakan }\end{array}$ & $\begin{array}{l}\text { polusi } \\
\text { udara }\end{array}$ & 22 & 68,18 \\
& $\begin{array}{l}\text { Keindahan } \\
\text { Rekreasi }\end{array}$ & 6 & 100 \\
\hline $\begin{array}{l}\text { Setujukah anda apabila dengan } \\
\text { adanya hutan kota, anda } \\
\text { mendapatkan kesegaran , } \\
\text { kesejukan dan lingkungan yang } \\
\text { bersih }\end{array}$ & setuju & 22 & 100 \\
\hline $\begin{array}{l}\text { Setujukah anda bahwa masalah } \\
\text { pencemaran lingkungan dikota }\end{array}$ & setuju & 0 & 0 \\
$\begin{array}{l}\text { Sorong, salah satu alternative } \\
\text { pemecahannya adalah dengan } \\
\text { mengembangkan program } \\
\text { hutan kota. }\end{array}$ & tidak & 22 & 100 \\
\hline
\end{tabular}

Sumber : Data Olahan Penelitian 2015

Tabel 7 menunjukan bahwa masyarakat Kelurahan Remu Selatan $100 \%$ menyatakan bahwa bentuk pemanfaatan hutan kota dapat dirasakan manfaatnya sebagai hutan kota bagi masyarakat. Masyarakat Kelurahan Remu Selatan sebanyak 100\% menyatakan manfaat dari hutan kota yang ada yaitu manfaatnya terhadap keindahan kota, , Hal ini bertujuan untuk meningkatkan estetika atau keindahan kota, sehingga memiliki nilai kebanggaan tersendiri pada Kota Sorong. Masyarakat Kelurahan Remu Selatan 100\% setuju dengan adanya hutan kota akan memberikan kesegaran, kesejukan dan keindahan kota 100\% dan masalah pencemaran dapat teratasi dengan adanya pengembangan program hutan kota Dengan demikian persepsi masyarakat Kelurahan Remu selatan terhadap aspek pemanfaatan hutan kota tergolong tinggi. Bentuk dukungan dari masyarakat tersebut dapat dijadikan sebagai bahan masukan dalam program

pengembangan dan pembangunan hutan kota di Kota Sorong. Pemerintah dapat mempertimbangkan aspirasi dari masyarakat tersebut sebagai pengambilan kebijakan dan keputusan dalam program pengembangan hutan kota.

\section{Persepsi Masyarakat Terhadap Aspek Pengelolaan Hutan Kota}

\section{a. Persepsi Masyarakat Kelurahan Malaingkedi Terhadap Aspek Pengelolaan Hutan Kota \\ Persepsi masyarakat Kelurahan} Malaingkedi terkait dengan pengelolaan hutan kota menyatakan bahwa pengelolaan hutan kota masih sangat kurang pengelolaannya dan perlu adanya peningkatan. Peningkatan tersebut ditandai dengan adanya penambahan sarana dan prasarana. Tingkat persepsi masyarakat Kelurahan Malaingkedi terhadap aspek 
pengelolaan hutan kota dapat dilihat

pada Tabel 8 di bawah ini.

Tabel 8. Tingkat Persepsi Masyarakat Kelurahan Malaingkedi terhadap Aspek Pengelolaan Hutan Kota

\begin{tabular}{|c|c|c|c|c|}
\hline No. & Uraian & & Responden & Persentasi $(\%)$ \\
\hline \multirow{3}{*}{1.} & \multirow{3}{*}{$\begin{array}{l}\text { Peran dari Pemerintah Daerah Kota } \\
\text { Sorong dalam upaya pengelolaan } \\
\text { dan pemeliharaan hutan kota yang } \\
\text { ada di Kota Sorong. }\end{array}$} & & & \\
\hline & & Baik & 2 & 16,67 \\
\hline & & Tidak & 10 & 83,33 \\
\hline \multirow[t]{2}{*}{2.} & \multirow{2}{*}{$\begin{array}{l}\text { Masyarakat perlu dilibatkan dalam } \\
\text { pengelolaan dan pemeliharaan } \\
\text { hutan kota di kota sorong }\end{array}$} & Perlu & 12 & 100 \\
\hline & & Tidak perlu & 0 & 0 \\
\hline \multirow[t]{2}{*}{3.} & $\begin{array}{l}\text { Kkawasan Bandara Deo yang } \\
\text { merupakan kawasan hutan kota } \\
\text { memberikan manfaat terhadap }\end{array}$ & $\mathrm{Ya}$ & 12 & 100 \\
\hline & lingkungan kota Sorong. & Tidak & 0 & 0 \\
\hline
\end{tabular}

Sumber : Data Olahan Penelitian 2015

Tabel 8 menunjukan bahwa persepsi masyarakat Kelurahan Malaingkedi terkait dengan pengelolaan hutan kota sebanyak $83,33 \%$ menyatakan bahwa pengelolaan hutan kota masih sangat kurang pengelolaannya dan perlu adanya peningkatan,masyarakat menyatakan bahwa peran pemerintah daerah dalam hal ini instansi terkait (Dinas Lingkungan Hidup) dalam hal pengelolaan dan pengembangan hutan kota harus ditingkatkan dengan membuat program-program penanaman pohon pada daerah-daerah kritis di kota Sorong. Persepsi masyarakat perlu dilibatkan dalam pengelolaan dan pemeliharaan hutan kota sebesar $100 \%$, masyarakat/responden berpendapat bahwa kawasan hutan kota memberikan manfaat terhadap lingkungan Kota Sorong, sehingga kota Sorong akan menjadi yang bersih, indah dan nyaman.

b. Persepsi Masyarakat Kelurahan Remu Selatan Terhadap Aspek Pengelolaan Hutan Kota

Presepsi masyarakat Kelurahan Remu Selatan terkait dengan pengelolaan hutan kota menyatakan bahwa pengelolaan hutan kota masaih sangat kurang pengelolaannya dan perlu adanya peningkatan. Tingkat presepsi masyrarakat Kelurahan Remu Selatan terhadap aspek pengelolaan hutan kota dapat dilihat pada tabel 9 di bawah ini. 


\section{Median Volume IX Nomor 1 Bulan Februari 2017}

Tabel 9. Tingkat Persepsi Masyarakat Kelurahan Remu Selatan terhadap Aspek Pengelolaan Hutan Kota

\begin{tabular}{|c|c|c|c|c|}
\hline No. & Uraian & & Responden & $\begin{array}{c}\text { Persentasi } \\
(\%)\end{array}$ \\
\hline \multirow[t]{2}{*}{1.} & \multirow{2}{*}{$\begin{array}{l}\text { Peran dari Pemerintah Daerah Kota } \\
\text { Sorong dalam upaya pengelolaan } \\
\text { dan pemeliharaan hutan kota yang } \\
\text { ada di Kota Sorong. }\end{array}$} & Baik & 1 & 4,55 \\
\hline & & Tidak & 21 & 95,45 \\
\hline \multirow{2}{*}{2.} & \multirow{2}{*}{$\begin{array}{l}\text { Masyarakat perlu dilibatkan dalam } \\
\text { pengelolaan dan pemeliharaan } \\
\text { hutan kota di kota sorong }\end{array}$} & Perlu & 22 & 100 \\
\hline & & Tidak perlu & 0 & 0 \\
\hline \multirow[t]{2}{*}{3.} & $\begin{array}{l}\text { Kkawasan Bandara Deo yang } \\
\text { merupakan kawasan hutan kota } \\
\text { memberikan manfaat terhadap }\end{array}$ & Ya & 22 & 100 \\
\hline & lingkungan kota Sorong. & Tidak & 0 & 0 \\
\hline
\end{tabular}

Sumber : Data Olahan Penelitian 2015

Tabel 9 menunjukan bahwa persepsi masyarakat Kelurahan Remu Selatan terkait dengan pengelolaan hutan kota sebanyak $95,45 \%$ menyatakan bahwa pengelolaan hutan kota masih sangat kurang pengelolaannya dan perlu adanya peningkatan, masyarakat menyatakan bahwa peran pemerintah daerah dalam hal ini instansi terkait (Dinas Lingkungan Hidup) dalam hal pengelolaan dan pengembangan hutan kota harus ditingkatkan dengan membuat program-program penanaman pohon pada daerah-daerah kritis di kota SorongPersepsi masyarakat perlu dilibatkan dalam pengelolaan dan pemeliharaan hutan kota sebesar $100 \%$, masyarakat/responden berpendapat bahwa kawasan hutan kota memberikan manfaat terhadap lingkungan Kota Sorong.

\section{Persepsi Pengelola Terhadap Hutan Kota Berupa Taman Kota}

\section{Di Depan Bandara Deo Kota Sorong}

Hasil wawancara dengan pihak pengelola dalam hal ini Dinas Lingkungan Hidupyaitu perlu dibangun hutan kota di tengah-tengah kota sebagai paru-paru kota dan di areal permukiman untuk kepentingan masyarakat sekitar serta pembangunannya di lokasi-lokasi tertentu yang diperlukan. Hal ini terkait dengan pemanasan global, sebagai penyerapan polusi udara, peredam kebisingan, penghijauan, dan rekreasi. Bentuk hutan kota yang diperlukan menurut pihak pengelola yaitu Taman Kota dan dilakukan untuk meningkatkan keindahan Kota Sorong. Taman kota selain untuk memperindah kota, juga dibangun untuk penyegaran terhadap masyarakat sehingga pikiran dan emosi dari masyarakat juga dapat kembali menjadi segar dan kinerja atau produktifitas masyarakat menjadi lebih baik. Hal ini selanjutnya dapat 


\section{Median Volume IX Nomor 1 Bulan Februari 2017}

mempengaruhi pendapatan dan stabilitas perekonomian di perkotaan. Taman kota dapat dibangun di areal permukiman pada lahan fasilitas umum yang diberdayakan oleh masyarakat Menurut Dahlan (1992) kota yang sakit, tercemar dan kotor dapat menyebabkan pejabat pemerintah kemungkinan tidak lagi dapat berpikir dengan tenang, tajam dan terarah, sehingga kemampuannya dalam memecahkan masalah yang kompleks dan futuristik akan menurun. Selain itu, masyarakat yang ada juga dapat menurun kinerja dan produktifitasnya, sehingga pada akhirnya menghasilkan kekuatan dan masa depan negara yang lemah dan suram.

Pihak pengelola menyatakan bahwa masyarakat perlu dilibatkan dalam kegiatan pengelolaan dan pemeliharaan hutan kota yang ada, tapi sifatnya tidak secara langsung. Hal ini dilakukan dengan cara menumbuhkan kesadaran dari masyarakat itu sendiri agar ikut menjaga kebersihan dengan tidak membuang sampah secara sembarangan, tidak melakukan pengrusakan terhadap pohon-pohon yang ada di dalam hutan kota, dan menciptakan suasnaa yang hijau di areal permukimannya.

\section{KESIMPULAN} adalah :

Kesimpulan dari penelitian ini

1. Persepsi masyarakat Kelurahan Malaingkedi terhadap aspek pengenalan hutan kota yaitu; 83,33 $\%$ mengetahui tentang hutan kota, $100 \%$ setuju dengan adanya hutan kota, 83,33 \% mengetahui tentang keberadaan hutan kota dan 66,67\% berpendapat bahwa hutan kota di Kota Sorong dalam kondisi rusak. Persepsi masyarakat Kelurahan sekitar dan perlu dibantu serta didukung oleh pemuka masyarakat dan pemerintah Kota Sorong.

Malaingkedi terhadap aspek pemanfaatan hutan kota yaitu; $100 \%$ masyarakat/responden mengatakan hutan kota bermanfaat, $100 \%$ masyarakat/responden berpendapat bentuk manfaat yang dirasakan dari hutan kota adalah mengurangi polusi udara dan $\quad 100 \quad \%$ Masyarakat/responden setuju dengan adanya hutan kota dapat memberikan kesegaran, kesejukan dan lingkungan yang bersih serta merupakan salah satu alternatif pemecahan masalah pencemaran lingungan di kota Sorong.

2. Persepsi masyarakat Kelurahan Remu Selatan terhadap aspek pengenalan hutan kota yaitu; 86,36 $\%$ mengetahui tentang hutan kota, $100 \%$ setuju dengan adanya hutan kota, 86,36 \% mengetahui tentang keberadaan hutan kota dan 95,45 \% berpendapat bahwa hutan kota di Kota Sorong dalam kondisi rusak. Persepsi masyarakat Kelurahan Remu Selatan terhadap aspek pemanfaatan hutan kota yaitu; 100 $\%$ masyarakat/responden mengatakan hutan kota bermanfaat, $100 \%$ masyarakat/responden berpendapat bentuk manfaat yang dirasakan dari hutan kota adalah memberikan keindahan dan $100 \%$ Masyarakat/responden setuju dengan adanya hutan kota dapat memberikan kesegaran, kesejukan dan lingkungan yang bersih serta merupakan salah satu alternatif pemecahan masalah pencemaran lingungan di kota Sorong. 


\section{Median Volume IX Nomor 1 Bulan Februari 2017}

\section{DAFTAR PUSTAKA}

Badan Pusat Statistika. 2015. Kota Sorong Dalam Angka 2015.

Dahlan 1992. Hutan Kota Untuk Pengelolaan dan Peningkatan

Fandeli. C, Kaharuddin, Mukhlison., 2003. Perhutanan Kota. Fakultas Kehutanan Universitas Gajah Mada. Yokyakarta.

Fandeli. C, 2000. Pengelolaan Perhutanan Kota. Makalah disampaikan pada Kursus Pembangunan Hutan Kota. LPP Wana Wiyata Yogyakarta.

Fuad, M. J. 2003. Persepsi Masyarakat Perkotaan Terhadap Hutan Kota Di Kabupaten Serang (Studi Kasus Masyarakat Kelurahan Cipare, Kecamatan Serang) [karya ilmiah]. Bogor : Program Diploma III Konservasi Sumberdaya Hutan Departemen Konservasi Sumberdaya Hutan Fakultas Kehutanan. Institut Pertanian Bogor. Tidak diterbitkan.

Hasto Tri Djatmiko, 2008. Persepsi Masyarakat Perkotaan Terhadap Hutan Kota. Skripsi. IPB Bogor

Mauludin, Uu. 1994. Persepsi Masyarakat Kotamadya Bogor Terhadap Hutan Kota Di Wilayah Kotamadya Bogor (Studi Kasus Di Kecamatan Bogor Timur dan Bogor Selatan) [skripsi]. Bogor : Jurusan Konservasi Sumberdaya Hutan Fakultas Kehutanan. Institut Pertanian Bogor. Tidak diterbitkan.

Pamungkas, S. M. 2006. Persepsi Masyarakat Lokal Mengenai Pengelolaan Sumberdaya Hutan Di Hutan Lindung Gunung Lumut Kalimantan Timur. [skripsi]. Bogor : Departemen Konservasi Sumberdaya Hutan Fakultas
Kualitas Lingkungan Hidup. Asosiasi Pengusaha Hutan Indonesia. Jakarta

Dahlan 2004. Membangun Kota Kebun (Garden City) Bernuansa Hutan Kota. IPB Press. Bogor.

Kehutanan. Institut Pertanian Bogor. Tidak diterbitkan.

Purwanto, B. 1998. Studi Persepsi Dan Interaksi Masyarakat Terhadap Lingkungan Hijau Pada Hutan Kota Tipe Permukiman (Studi Kasus Di Kelurahan Cengkareng Barat, Jakarta Barat). [skripsi]. Bogor : Jurusan Konservasi Sumberdaya Hutan Fakultas Kehutanan. Institut Pertanian Bogor. Tidak diterbitkan.

Surata, S. P. K. 1993. Persepsi Seniman Lukis Tradisi Bali Terhadap Konservasi Burung. [tesis]. Bogor : Program Pascasarjana, Institut Pertanian Bogor. Tidak diterbitkan.

Umar, 2009. Persepsi dan Perilaku Masyarakat Dalam Pelestarian Fungsi Hutan Sebagai Daerah Resapan Air ( studi kasus hutan Penggaron Kabupaten Semarang ). Thesis. Universitas Diponegoro Semarang.

Unradjan, D. 2000. Pengantar Metode Penelitian Ilmu Sosial. Grasindo. Jakarta.

Zakih, A. 1997. Perbandingan Persepsi Masyarakat Kota Moderen Dengan Masyarakat Kampung Kota Terhadap Hutan Kota Di Kecamatan Kebayoran Baru Jakarta Selatan. [skripsi]. Bogor : Jurusan Konservasi Sumberdaya Hutan Fakultas Kehutanan. Institut Pertanian Bogor. Tidak diterbitkan. 